\title{
酸化コバルトと酸化鉄間の薄膜反応による コバルトフェライトの合成
}

\author{
(1980 年 10 月 21 日受理) \\ 山崎陽太 郎*・並河建・佐藤 実
}

コバルトフェライト薄膜を, 酸化鉄薄膜と酸化コバルト薄膜の界面に拈ける固相反応により合成し， 膜の組織, 組成分布, 磁気特性およびフェライト相の生成過程について検討を行なった。フェライト生 成反応は $\mathrm{Fe}_{3} \mathrm{O}_{4}$ 膜と酸化コバルト膜の界面では, 低温度 $\left(400^{\circ} \mathrm{C}\right)$ で進行し, 厚さ $0.44 \mu \mathrm{m}$, 平均結晶 粒径 $0.03 \mu \mathrm{m}$ の連続体薄膜を作製することができた。このフェライト薄膜は滑らかな表面を有し，透 明であり, かつ高い保磁力を示し，その值は熱処理条件によって $1.5 \mathrm{kOe}$ から $5.0 \mathrm{kOe}$ まで変化し た。また生成薄膜中のコバルト濃度分布を AESにより測定し，拡散係数の概算を行なった結果，上記 反応温度において膜中のコバルトの移動速度が比較的速い $\left(D \doteqdot 10^{-15} \mathrm{~cm}^{2} / \mathrm{s}\right)$ ことを認めた。一方， $\alpha-$ $\mathrm{Fe}_{2} \mathrm{O}_{3}$ 膜と酸化コバルト膜との界面では, $500^{\circ} \mathrm{C}$ ま昇温し熱処理を行なってもフェライト生成反応は 認められなかった。

\section{1 楮言}

磁気記録に用いる磁性薄膜は, 従来針状の $\gamma-\mathrm{Fe}_{2} \mathrm{O}_{3}$ 粉末をバ インダーと混合し塗布することによって作製されてきた。一方, 最近の情報処理技術の急速な発達によって，さらに記録密度の高 い磁性材料が要求されている。このような背景のもとで, 磁気記 録媒体を従来の塗膜型から連続膜へ変える試みがなされ，石井2), 寺田 ${ }^{8)}$, 徳吉ら ${ }^{4}$ (はスパッタ法により $\alpha-\mathrm{Fe}_{2} \mathrm{O}_{3}$ 薄膜を作製し, こ れを水素気流中で還元し，得られた $\mathrm{Fe}_{3} \mathrm{O}_{4}$ 膜を低温で酸化する ことにより, $\gamma-\mathrm{Fe}_{2} \mathrm{O}_{3}$ 連続薄膜を作製している。またこれ以前に 稲垣ら ${ }^{5)}$ は, アルミナ多結晶板上飞蒸着した鉄薄膜の表面をアル カリ化成処理したのち $1000^{\circ} \mathrm{C}$ 以上の高温で酸化し， $\alpha-\mathrm{Fe}_{2} \mathrm{O}_{3}$ 膜 を作製し，これを低温で還元して $\mathrm{Fe}_{3} \mathrm{O}_{4}$ 薄膜を得ている。

本研究では, フェライト薄膜を合成する方法として, 原料酸化 物の 2 層薄膜を真空蒸着法と低温酸化法とを用いて作製し,これ を減压下で熱処理することによって薄膜間に固相反応を生じさ せ, 高い保磁力をもった磁気記録用フェライト薄膜を合成するプ 口セスを提案し, その生成過程および各段階で得られる膜の構造 を解析することを目的としている。本報告で述べるフェライト薄

東京工業大学総合理工学研究科電子化学専攻, 227 横浜 市緑区長津田町

1）この報文を“フェライト連続薄膜の合成に関する研究（第 1 報)”とする.

2）石井芳一, 服部誠示, 太田 聡, 牧野宏一, 川上, 進, 電 子通信学会磁気記録研究会資料, MR 78-20，9(1978).

3）寺田 章, 石井 修, 野原 瑛, 篠原正竟, 中川雄彦, 電 子通信学会磁気記録研究会資料, MR 78-20，19(1978).

4）德吉睦生, 服部誠示, 石井芳一, 寺田 章, 石井修, 日 本応用磁気学会誌，3，43(1979).

5）稲垣伸夫, 服部誠示, 石井芳一, 電気通信研究所研究実用 化報告, 24, 2765(1975).
膜の合成法は，著者ら (0) 12) によって検討と改良が行なわれてきた ものであり, 従来高温 $\left(900^{\circ} \mathrm{C}\right.$ 以上) に扎いて合成が行なわれて きたフェライト連続体を, 比较的低温 $\left(400^{\circ} \mathrm{C}\right)$ で合成する点を特 徵としている。低温で合成したフェライト薄膜は結晶粒径が小さ く，微細な組織を有することから，磁気記録媒体としてすぐれた 特性を示すことが期待される。また本研究で用いた薄膜作製法 は，ほかの薄膜電子材料の合成にも利用できると思われる。

\section{2 実験}

\section{1 薄膜合成法}

フェライトは複酸化物であり，一般式 $\mathrm{MOFe}_{2} \mathrm{O}_{3}$ で表わせる。 本研究ではMとしてコバルトを選び, 酸化コバルトと酸化鉄薄膜 よりなる 2 層膜を熱処理することによりコバルトフェライト薄膜 を合成した。薄膜の特性は，合成条件のわずかの違いにより大き く変化することが多い。本研究に括いては再現性のあるデータを 収得するために, 合成条件が一義的に定まるよら考慮し,ささらに 異なった装置を用いてる同一の特性をもった薄膜が得られるよう 条件の設定に留意し合成を行なった。四 1 亿合成過程を示し, 以 下にその各段階について示す。

\section{2 基板材料}

薄膜合成用基板は，以下に示す条件を満たすことが望むしい。

6) 花形澄雄, 修士論文, 東京工業大学 (1975).

7）兼子 正, 山崎陽太郎, 佐藤 実, 電子通信学会磁気記録 研究会資料, MR 75-21，1(1975).

8）兼子 正, 修士論文, 東京工業大学 (1977).

9) M. Satou, T. Namikawa, T. Kaneko, Y. Yamazaki, IEEE Trans. Magn., MAG-13, 1400(1977).

10）山崎陽太郎, 佐藤 実, 電子通信学会磁気記録研究会資料, MR 79-26, 9(1980).

11) 蔭山康秀, 修士論文, 東京工業大学 (1980).

12）土屋一広, 修士論文, 東京工業大学 (1980). 


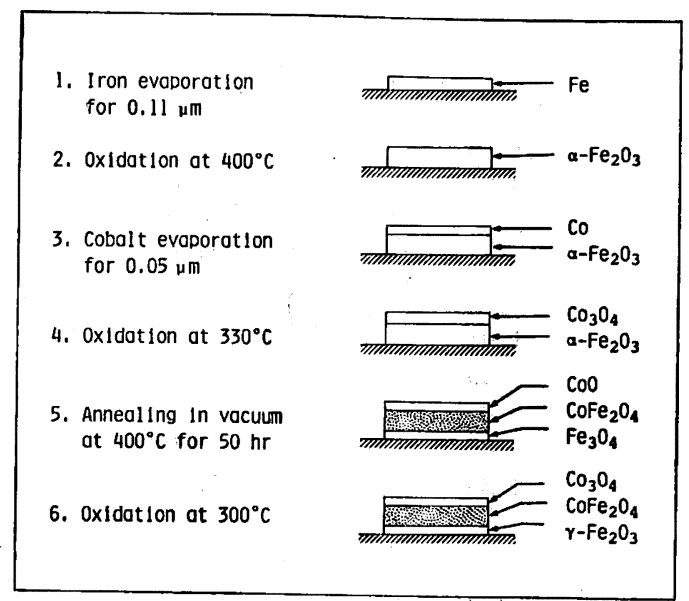

Fig. 1 Preparation process of polycrystalline cobalt ferrite thin films

1）蒸着物質と反応しないこと，2）精度の高い平面を有するこ と，3）化学的に不均一な領域たと光ば結晶粒界などができるた け少ないこと，4）つねに同一品質のものが入手できること，5） 透光性があること，できれば光学等方体であること，6）熱衝撃 に強いこと，7）室温，大気中で安定に保存できること，8）熱 膨張係数が適切であること，などの条件があげられる。これらを すべて満足する基板材料を見いだすことは因難であり, 予備実験 で比较的良好な特性を示した $\alpha-\mathrm{Al}_{2} \mathrm{O}_{3}$ 単結晶板（信光社製）を 使用した。基板の厚さは $1 \mathrm{~mm}$ であり，両面を同社において光 学研磨したものである。

\section{3 基板の前処理および真空蒸着}

蒸着基板表面の污れは生成薄膜の再現性をいちじるしく低下さ せる。このため本実験では基板を中性洗剂洗浄，水洗，塩酸 (20 $w \mathrm{t} \%$ ) 洗浄, 水洗したのちに沸騰アセトン中で 30 分洗浄を行な い,ただちに蒸着室へセットし，排気を行ない $9 \times 10^{-4} \mathrm{~Pa}$ の真 空中で $400^{\circ} \mathrm{C}, 1$ 時間ベーキングを行ない, 吸着物質の脱離を計 った。

蒸着条件の中で生成膜の特性に影響を括よぼするのは, 真空 度, 基板温度, 蒸着速度(堆積速度)および蒸発源温度である。こ のほかに膜の不純物濃度に影響を与える要因として蒸発原料の純 度, 蒸発用ルツボの材質, 発熱体およびその保持具の材質などに 考慮する必要がある。本研究では高純度鉄怙よびュバルト (Johnson Mattey Chemicals Ltd., 純度 99.99\%) を蒸発原料とし, 蒸発速度および蒸発源温度がばらつかないよらに原料チャージ量 を一定にたもち，蒸着速度は水晶振動子式膜厚計 (Sloan Instruments Co., Model DTM-4) を用いて監視を行なった。蒸着条件 を表 1 に示す。

\section{4 蒸着膜の酸化}

蒸着した鉄およびュバルト金属薄膜を逐次酸化し，酸化物 2 層 薄膜を作製するさいの鉄薄膜の酸化過程は，フェライト膜合成プ ロセスの中でもっとも重要であり，初期の合成研究(3)8) に打いて は, 再現性のある均一な $\alpha-\mathrm{Fe}_{2} \mathrm{O}_{3}$ 膜を得ることを目標にしてデ 一タの集積を行なった。鉄薄膜の酸化過程で急速に酸化反応が進 んた場合には，膜の組織が粗大となり，かつ面内配向が生じ，機 械的強度が低下する。一方，極端に低温で酸化を行ならと，鉄膜 の表面に緻密な酸化物被膜が生成し，その後の酸化反応が進行
Table 1 Evaporation condition
Source material
Film thickness

Substrate temperature

Chamber pressure

Distance between the source and the stubstrate.

Surface area of evaporation source Crucible material
Film formation rate
Fe, Co

$0.11 \mu \mathrm{m}$ for $\mathrm{Fe}$, $0.055 \mu \mathrm{m}$ for $\mathrm{Co}$ $0.011 \mu \mathrm{m} / \mathrm{min}$ $350^{\circ} \mathrm{C}$ $4 \times 10^{-3} \mathrm{~Pa}$ $40 \mathrm{~cm}$

$2.0 \mathrm{~cm}^{2}$ $\alpha-\mathrm{Al}_{2} \mathrm{O}_{3}$
Table 2 Oxidation conditions

$\begin{array}{ll}\text { Heating rate } & 10^{\circ} \mathrm{C} / \mathrm{min} \\ \text { Reaction temperature } & 400^{\circ} \mathrm{C} \\ \text { Reaction time } & 3 \mathrm{~h} \\ \text { Atmosphere } & \mathrm{O}_{2} \text { saturated with } \mathrm{H}_{2} \mathrm{O} \text { at } 20^{\circ} \mathrm{C}\end{array}$

しなくなる。一度このような被膜が生成してしまうと，その後温 度を上げても均一な酸化反応は開始されず良好な $\alpha-\mathrm{Fe}_{2} \mathrm{O}_{3}$ 膜を 得ることはできなかった。表 2 に良好な結果が得られたときの条 件を示す。

\section{5 真空熱処理およびフェライト膜の酸化}

真空蒸着と酸化処理によって作製した原料酸化物 2 層膜 $\left(\mathrm{Co}_{3}\right.$. $\mathrm{O}_{4} / \alpha-\mathrm{Fe}_{2} \mathrm{O}_{3}$ 膜) の熱処理は, $9 \times 10^{-4} \mathrm{~Pa}$ の真空中 $400^{\circ} \mathrm{C}$ で行 なった。試料は板状ヒーターからの輻射により加熱し，熱処理終 了後はただちに真空熱処理室にアルゴンガスを導入し, 試料を冷 却した。昇温速度および冷却速度はおのおの $230^{\circ} \mathrm{C} / \mathrm{min}$ おび $100^{\circ} \mathrm{C} / \mathrm{min}$ であり，熱処理時間は 50 時間までとした。

熱処理により生成したコバルトフェライトは・ $\mathrm{Fe}_{3} \mathrm{O}_{4}$ および $\boldsymbol{\gamma}$ $\mathrm{Fe}_{2} \mathrm{O}_{3}$ ときわめて類似したX線回折図形を示すので，これを確認 するために他の方法を考える必要がある。本研究ではコバルトフ ェライトの保磁力が，熱処理中の酸素分圧に大きく依存する ${ }^{18)}$ 点 に着目し，これによりコバルトフェライトの生成を確認した。熱 処理は $300^{\circ} \mathrm{C}$ で 5 時間酸素気流中で行なった。

\section{3 結果}

\section{1 結晶粒径および配向}

本研究では最終的なフェライト膜を得るまでに多くの固相反応 を経ている。固相反応では反応物質の組織が変化するので，本研 究では前述の合成過程の各段階で膜の結晶粒径とその配向をX線 回折により調べた。使用した回析装置は日本電子社製 JDX-8 S であり,グラファイトのモノクロメーターDX-GOM 2 を用いて バックグラウンドノイズの低減を計った。

蒸着鉄薄膜は $\alpha$ 相の鉄ピークのみが検出され，目立った配向は 認められなかったが，これを酸化して得られた $\alpha-\mathrm{Fe}_{2} \mathrm{O}_{3}$ 膜には 強い配向が見られた。 $\alpha-\mathrm{Fe}_{2} \mathrm{O}_{3}$ 膜について得られた回折ピーク 強度を表 3 に示す。表には ASTM ファイルから引用した無配向 の場合の回折強度およびその值と測定値との比較を，各回折面に ついて示し，さらにそれらの面の法線が $c$ 軸となす角度を示し た。表から明らかに $c$ 軸方向を向いている面からの回折強度が増 加して找り，生成 $\alpha-\mathrm{Fe}_{2} \mathrm{O}_{3}$ 膜が，酸素原子の最密面である (006) 面を基板に平行にして生成する傾向があることを示している。鉄 および $\alpha-\mathrm{Fe}_{2} \mathrm{O}_{3}$ 膜の各最強回折ピーク ((110) および (104))

13）熊代幸伸, 学位論文, 東京工業大学, p. 65(1969). 
Table $3 \mathrm{X}$-ray diffraction intensity of the prepared $\alpha-\mathrm{Fe}_{2} \mathrm{O}_{3}$ film

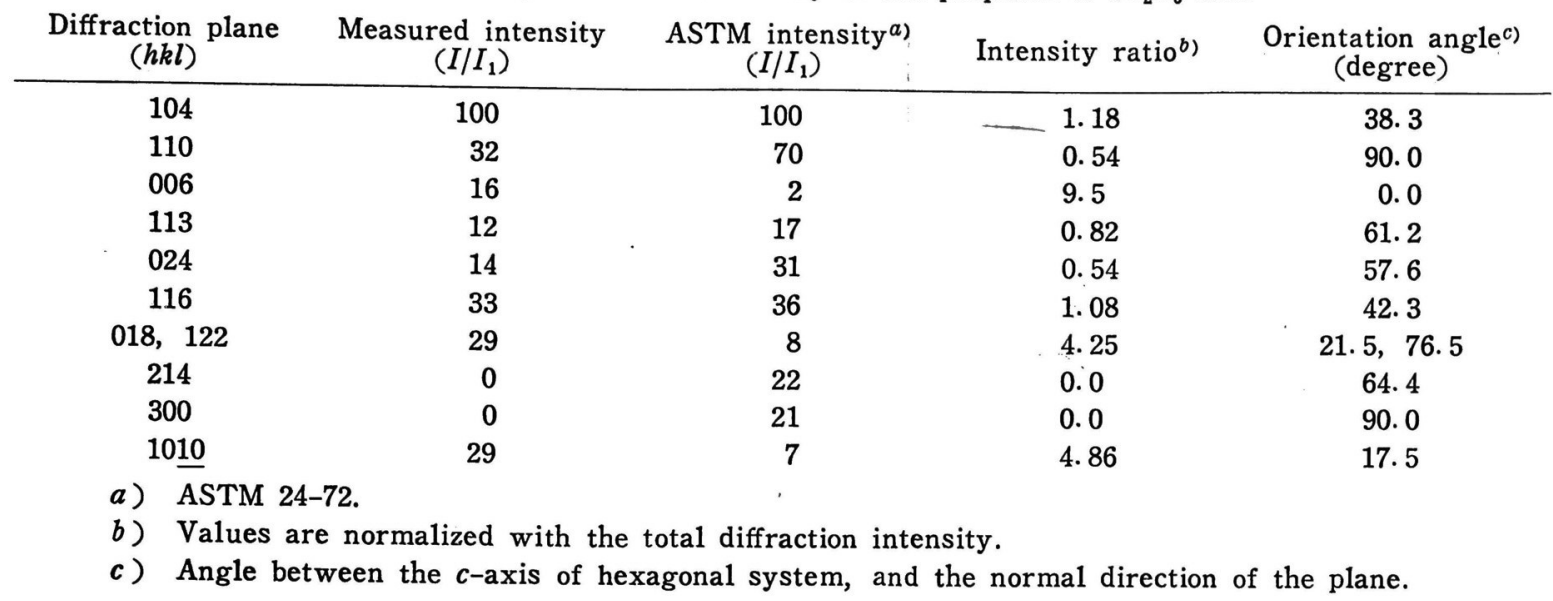

の半値幅から Sherrer の式を用いて求めた結晶粒径はおのおの $200 \AA$ および $330 \AA$ であった。

真空熱処理中の試料からはスピネルと $\mathrm{CoO}$ の回折ピークが得 られたが,これらには配向は認められなかった。また同スピネル の（311）ピークから求めた結晶粒径は $320 \AA$ であった。真空熱 処理後に酸化を行なった試料について同様に求めた結晶粒径は $280 \AA$ であり, 比較的大きな減少がみられた。

\section{2 膜の表面状態}

薄膜の表面構造は内部之異なりきわめて複雑であり,さらに多 結晶酸化物においてはその表面が微視的にまでなめらかである場 合は少ない。そのため単結晶試料の解析に有効な電子線回折法を 効果的に利用することが難かしい。本研究では蒸着鉄薄膜を酸化 して得られた $\alpha-\mathrm{Fe}_{2} \mathrm{O}_{3}$ 膜および最終生成物であるコバルトフェ ライト薄膜の表面状態を 2 段レプリカ法および走査型電顕により 観察し，考察を行なった。2段レプリカ法による観察は高い分解 能が得られるが, 試料表面の凹凸が反転して像に現われるため, 走查型電顕像とつき合わせ，正確な表面状態を把握するよう心が けた。

レプリカ法により得られた $\alpha-\mathrm{Fe}_{2} \mathrm{O}_{3}$ 膜の表面状態を図 2 に示 す。表面は滑らかであり, 径が $0.02 \mu \mathrm{m}$ ほどの微妙なくぼみ(図 中 $\mathrm{H}$ で示す) が約 $5 \times 10^{9} \mathrm{~cm}^{-2}$ の密度で存在し, さらに図中 $\mathrm{R}$ で示した線状の隆起 (長さ約 $0.2 \mu \mathrm{m}$, 幅 $0.02 \mu \mathrm{m}$ ) が約 $10^{9} \mathrm{~cm}^{-2}$ の密度で分布している。くぼみ H 発生原因は不明である。線状 隆起は蒸着鉄膜の酸化のさいに生ずる膜面内の圧縮応力と関連が あると思われるが，発生機構の詳細については不明である。図 3 に同一試料の走査型電顕像を示す。図中 $\mathrm{R}^{\prime}$ で示した明るく見え る部分が，図 2 に打いてRで示した隆起に相当すると思われる。

真空熱処理 50 時間後酸化を行なった試料の表面レプリカ像を 図 4 に示す。表面には径が約 $0.08 \mu \mathrm{m}$ の半球状粒子（図中 $\mathrm{M}$ で 示す）が $5 \times 10^{\circ} \mathrm{cm}^{-2}$ ほどの密度で存在している。この半球状粒 子は形状から酸化コバルトであると推定される。図中Bで示した 隆起は, $\alpha-\mathrm{Fe}_{2} \mathrm{O}_{3}$ 膜表面に見られた線状隆起（図 2 に Rでし た）の形跡であると思われる。 $\alpha-\mathrm{Fe}_{2} \mathrm{O}_{3}$ 膜表面に見られた微小 なくぼみは，生成コバルトフェライト膜表面にも認められた（図 4 にPで示す)。同一試料表面の走査型電顕像を図 5 に示す。

生成フェライト膜の断面近傍を観察し, 膜の連続性を確認する ために, 一部を剩離したコバルトフェライト膜のレプリカ像を調

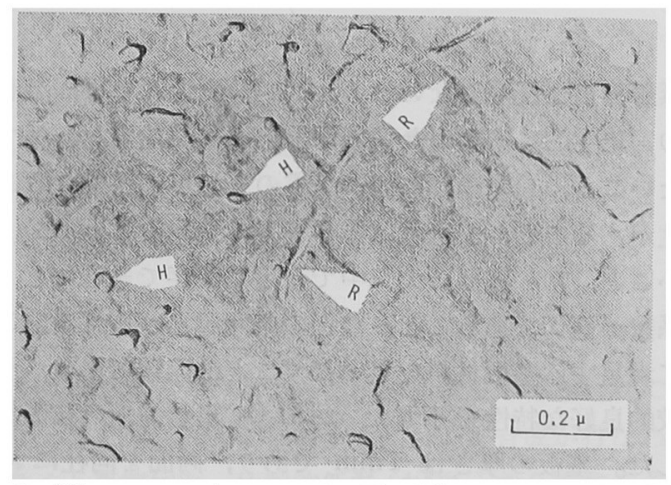

Fig. 2 Electron micrograph (double-stage replica) of the surface of the $\alpha-\mathrm{Fe}_{2} \mathrm{O}_{3}$ thin film formed at the process 2 shown in Fig. 1

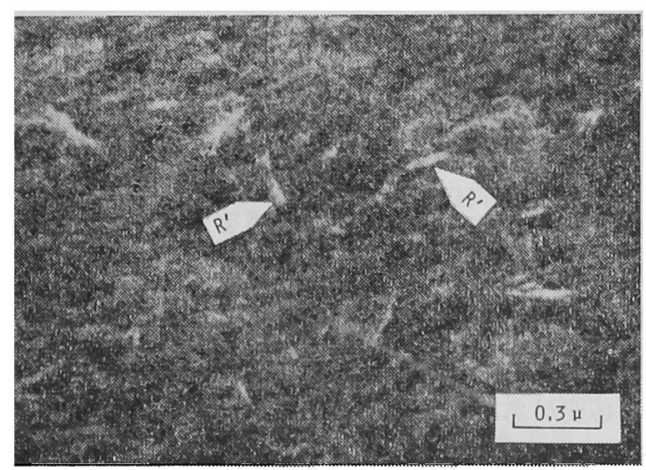

Fig. 3 SEM micrograph of the surface of the $\alpha-\mathrm{Fe}_{2} \mathrm{O}_{3}$ thin film

ベた。図6に破断したフェライト膜の像を示す。図中 G，C拉よ びSで示した部分は括の特の基板表面, 膜の破断面および膜の表 面である。図 4 および図 5 において見られた半球状粒子が膜表面 に存在しているが，巨視的なクラックあるいは膜を貫くピンホー ルなどは認められず，本研究で得られた膜は明らかに連続体であ ることがわかる。

\section{3 磁気特性}

、真空熱処理過程でュバルトフェライト相が生成することを確認 するために, 真空熱処理後の試料と, これを酸化処理したのちの 試料について磁気ヒステリシスループを測定し, 熱処理雾囲気と 


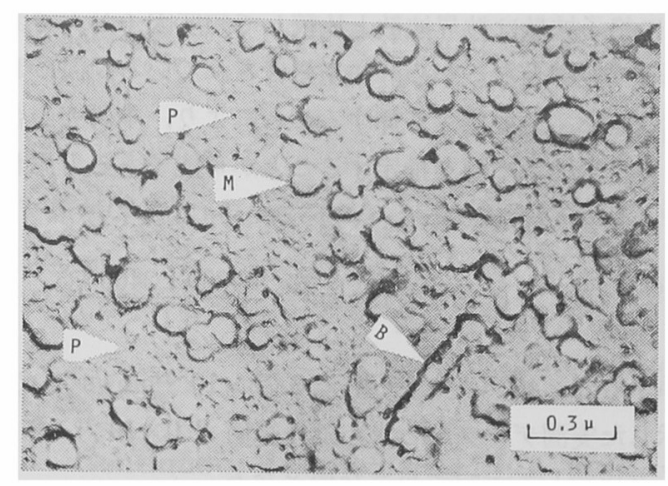

Fig. 4 Electron micrograph (doubl-stage replica) of the prepared cobalt ferrite thin film

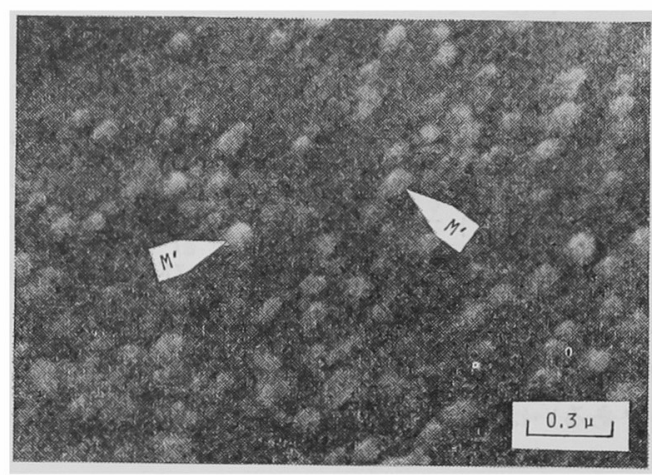

Fig. 5 SEM micrograph of the surface of the cobalt ferrite thin film

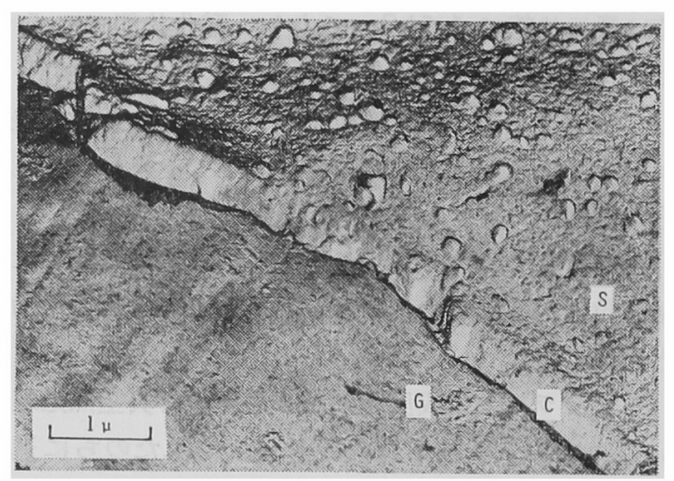

Fig. 6 Cross-section and surface of the prepared cobalt ferrite thin film

G : Surface of the substrate, C : Cross-section of the film, $S$ : Surface of the film

保磁力との関係を調べた。コバルトフェライトの保磁力が熱処理 中の酸素分王とともに大きく增加することは従来から垁験的に知 られている(13)。一方, $\mathrm{Fe}_{3} \mathrm{O}_{4}$ を酸化した場合には $\gamma-\mathrm{Fe}_{2} \mathrm{O}_{3}$ また は $\alpha-\mathrm{Fe}_{2} \mathrm{O}_{3}$ が生成するが，そのさいの保磁力の增加はコバルト フェライトほど顕著ではない。眓 7 に測定したヒステリシスルー プを示す。酸化後の保磁力は $5.0 \mathrm{kOe}$ ときわめて大きな值を示 し、コバルトフェライトが生成したものと思われる。また同ヒス テリシスループには $2.0 \mathrm{kOe}$ 近傍に屈曲点 (図中Xで示す) が見 られ，わずかではあるが保磁力の小さい強磁性相の存在も認めら れる。

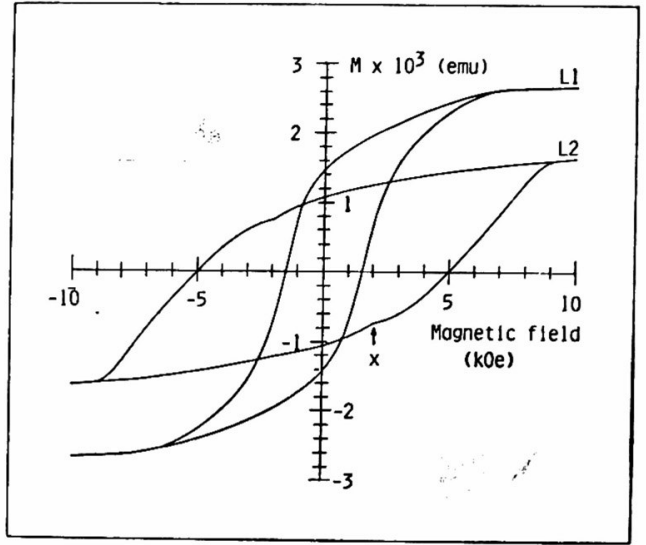

Fig. 7 Magnetic hysteresis loops of the prepared cobalt ferrite films in reduced and oxidized states

L 1 : After vacuum annealing, L 2: After oxidation

\section{4 考察}

\section{1 フェライト膜生成反応}

本研究では $\mathrm{Co}_{3} \mathrm{O}_{4} / \alpha-\mathrm{Fe}_{2} \mathrm{O}_{3} 2$ 層膜を真空中 $400^{\circ} \mathrm{C}$ で熱処理す ることによってコバルトフェライト膜を得たが，このさいにフェ ライト生成反応にさき立って $\mathrm{Co}_{3} \mathrm{O}_{4} \longrightarrow \mathrm{CoO}$ および $\alpha-\mathrm{Fe}_{2} \mathrm{O}_{3}$ $\longrightarrow \mathrm{Fe}_{3} \mathrm{O}_{4}$ の還元反応が進行することが，X 線回折により確認 された。その後熱処理時間とともに $\mathrm{CoO}$ の (200) 回折ピーク強 度が減衰する (表 4 参照) ことから，フェライト相の生成反応は 塩化ナトリウム構造の $\mathrm{CoO}$ とスピネル構造の $\mathrm{Fe}_{3} \mathrm{O}_{4}$ との間で 進行すると思われる。

一方, $\mathrm{Co}_{3} \mathrm{O}_{4} / \alpha-\mathrm{Fe}_{2} \mathrm{O}_{3} 2$ 層膜を酸素気流中拉よびアルゴン気流 中で $500^{\circ} \mathrm{C}$ ま加熱してもフェライト生成反応は進まなかった。 このさいには前に述べた二つの還元反応が進んでいないことが X 線回折から確認されたため, 本研究において低温でフェライト生 成反応が進行した原因は主としてマグネタイト薄膜の高い反応性 によると考えられる。

\section{2 コバルト濃度分布}

生成フェライト膜をスパッタェッチしながらコバルトおよび鉄 の各オージェ電子強度を連続测定し, それぞれのイオンの膜厚方 向濃度分布を求めた。測定に使用した装置は Physical Electronics 社製 Model 590 であり、コバルトおよび鉄の特性ピークの

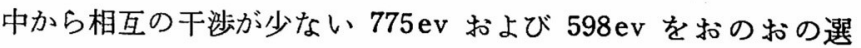
び，濃度分布測定を行なった。測定結果を図 8 に示す。試料の表 面ではコバルトの濃度が高く, 深さ方向へ進むにつれて低下して いるが，その濃度は 0 にはならず, 一定濃度の領域が広く存在 し, 膜の裏までかなりの量のコバルトが侵入していることがわか る。

また図 8 に示したコバルト濃度分布の测定結果から, 本研究に 牤けるマグネタイト膜中へのコバルトの拡散は，結晶粒界を通る 速い払散プロセスを含む系 ${ }^{14)}$ であることが予想される。速い粒界 拡散と革い格子払散とが共存する系に拈ける濃度分布の計算が鈴 風ら ${ }^{15}$ によって報告され, 図8に示した測定結果により近い分布

14） J.M.Poate, K.N. Tu, J. W. Mayer, "Thin Films-Interdiffusion and Reactions", John Wily \& Sons, New York (1978) p. 163.

15) T.Suzuoka, J. Phys. Soc. Jpn., 19, 839(1964). 
Table 4 Reduction of the (200) diffraction intensity of the $\mathrm{CoO}$ layer during the vacuum annealing process

\begin{tabular}{cc} 
Annealing time $(\mathrm{h})$ & Diffraction intensity (cps) \\
\hline 0 & 51 \\
13 & 32 \\
25 & 25 \\
50 & 21
\end{tabular}

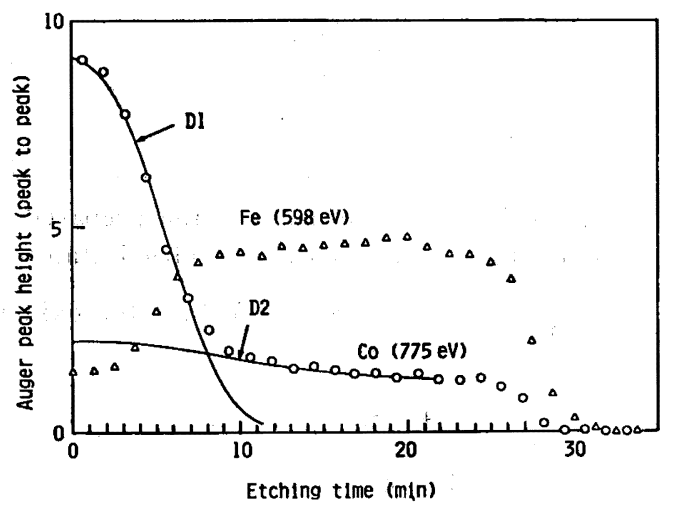

Fig. 8 Depth profiles for cobalt and iron concentrations in the formed cobalt ferrite thin film

D1 : Calculated curve with Eq. (1) for $D=3.0 \times 10^{-10}$ $\mathrm{cm}^{2} / \mathrm{s} ; \quad$ D $2:$ for $D=3.0 \times 10^{-15} \mathrm{~cm}^{2} / \mathrm{s}$

曲線が求められている。

\section{3 コバルトの㹡散速度}

図 8 に示したコバルト濃度分布の測定結果を用いて, 同イオン の払散速度の現象諭的な推定を行ならために, 払散方程式

$$
\frac{\partial c}{\partial t}=D \frac{\partial^{2} c}{\partial x^{2}}
$$

を以下の初期および境界条件で解き計算結果と測定結果との比較 を行なった。

$$
\begin{array}{lll}
c=c_{0}, & 0 \leqslant x \leqslant B, & t=0 \\
c=0, & B<x \leqslant L, & t=0 \\
\frac{\partial c}{\partial x}=0, & x=0, \quad L &
\end{array}
$$

ここで， $c$ は濃度， $c_{0}$ は反応開始時における膜の表面での濃度， $D$ は拡散係数， $B$ は酸化コバルト層の厚み， $L$ は全膜厚である。 $B=0.11 \mu \mathrm{m}, L=0.44 \mu \mathrm{m}, \quad D=3.0 \times 10^{-16} \mathrm{~cm}^{2} / \mathrm{s}$ および $B=$ $0.11 \mu \mathrm{m}, L=0.44 \mu \mathrm{m}, D=3.0 \times 10^{-15} \mathrm{~cm}^{2} / \mathrm{s}$ の場合の払散時間 50 時間に拈ける計算結果を図 8 に㬰線で示す。
一般に格子拡散は粒界拡散と比校して頻度因子が大であり，高 温において優勢となるため, 従来報告されている高温における抎 散係数の值を, 低温侧へ外挿することにより，本研究の合成温度 における格子拡散の值を推定することが可能であると思われる。 最近の Chen ら ${ }^{16)}$ によるコバルトフェライト中の拻散データ

$$
D_{\mathrm{Co}}=0.45 \pm 0.15 \exp \left(-\frac{64900 \pm 2400}{R T}\right)
$$

を外挿すると， $400^{\circ} \mathrm{C}$ では $D_{\mathrm{Co}}=3.78 \times 10^{-22} \mathrm{~cm}^{2} / \mathrm{s}$ となり，図 8 に示した実測データから求めた概算值 $3.0 \times 10^{-15} \sim 3.0 \times 10^{-10}$ $\mathrm{cm}^{2} / \mathrm{s}$ と比較して大幅に小さな值となる。

以上の結果からも本研究におけるコバルフェライト連続薄膜 の生成過程においては，速い粒界拡散が大きな役割を演じている と思われる。

\section{5 結 論}

蒸着金属薄膜を酸化し作製した $\mathrm{Co}_{3} \mathrm{O}_{4}$ および $\alpha-\mathrm{Fe}_{2} \mathrm{O}_{3}$ から なる 2 層膜を真空中に拈いて比較的低温 $\left(400^{\circ} \mathrm{C}\right)$ で熱処理するこ とによって，コバルトフェライト薄膜が合成できることを示し， さらに合成したフェライト薄膜の特性およびその生成過程を検討 し，以下に述べる結果を得た。

（1）合成したフェライト薄膜は連続体であり，膜を貫通する クラックあるいはピンホールなどの巨視的欠陥は認められなかっ た。

（2）合成したフェライト薄膜の平均結晶粒径は小さく約 300 Åであり, 結晶学的配向は認められなかった。

（3）合成したコバルトフェライト薄膜は高い保磁力を有し，

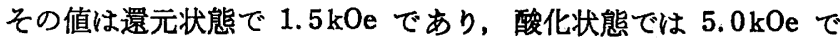
あった。

（4）合成フェライト薄膜のオーシェ電子分光分析結果によれ ば，コバルトイオンは合成薄膜の裹面まで侵入して括り，膜の内 部でその濃度が一定となる傾向が見られた。

（5）本研究に扰けるフェライト薄膜の生成過程では，原料薄 膜の結晶粒径が微細であるため粒界拡散による物質移動が促進さ れたと思われる。

（6）フェライト生成反応は，2 凮薄膜を真空熱処理する過程 に特いて， $\alpha-\mathrm{Fe}_{2} \mathrm{O}_{3}$ 膜が $\mathrm{Fe}_{3} \mathrm{O}_{4}$ に還元されたのちに進行し，他 の条件すなわち酸素あるいはアルゴン気流中では, $500^{\circ} \mathrm{C}$ ま昇 温し熱処理を行なっても，同先行反応が進行せずフェライトの生 成は認められなかった。

16) W.K. Chen, H. Downing, Phys. Status Solidi, 37, 515(1976) 


\title{
Preparation of Cobalt Ferrite by a Thin Film Reaction between \\ Cobalt Oxide and Iron Oxide Layers ${ }^{\dagger}$
}

\author{
Yohtaro Yamazaki*, Tatsuru Namikawa and Minoru Satou \\ Department of Electronic Chemistry, The Graduate School at \\ Nagatsuta, Tokyo Institute of Technology; Nagatsuta, \\ Midori-ku, Yokohama-shi 227 Japan
}

Continuous cobalt ferrite thin films which have a thickness of $0.44 \mu \mathrm{m}$ and a mean grain size of $0.33 \mu \mathrm{m}$ were prepared by a solid state reaction between cobalt monoxide and magnetite thin films at a relatively low temperature of $400^{\circ} \mathrm{C}$. The ferrite films were uniform and transparent, and no macroscopic defect was found on the surfaces. The magnetic coercive forces of the films were relatively high, and the value changed from $1.5 \mathrm{kOe}$ to $50 \mathrm{kOe}$ by heating the films at $300^{\circ} \mathrm{C}$ in different oxygen pressures. The distributions of cobalt content in the ferrite films were measured by means of Auger electron spectroscopy. The diffusion coefficient of the cobalt ions in the thin films at the reaction temperature was estimated using the distribution curve. The obtained value was about $10^{-15} \mathrm{~cm}^{2} / \mathrm{s}$. By comparing the result with the reported cobalt diffusivity in cobalt ferrite single crystals, it is concluded that the thin film reaction is substantially promoted by a mass transport process through the grain boundaries.

$\dagger$ Preparation of Polycrystalline Ferrite Thin Films. I. 